\title{
Credit expansion and development - A Schumpeterian and Keynesian view of the Chinese miracle
}

\author{
Hansjörg Herr*
}

\begin{abstract}
In neoclassical thinking, insufficient development is considered the result of a lack of resources, and an inefficient allocation. Deregulated markets have to guarantee a better allocation of resources as well as a net resource inflow to augment the domestic physical capital stock. From a Schumpeterian-Keynesian perspective, it is not the lack of physical resources and optimal allocation which prevent development. It is first and foremost the lack of a sufficient credit-investment mechanism which leads to the perpetuation of underdevelopment. It is shown here that the Schumpeterian-Keynesian perspective gives a much more plausible interpretation of the Chinese development than the neoclassical perspective. It is also shown under which regulations and conditions a credit-investment process in developing countries is possible.
\end{abstract}

JEL classifications: $E_{I 2}, E_{44}, F_{3} 6, F_{43}$

Keywords: credit, economic development, Schumpeter, Keynes, China

\section{Introduction}

Looking at GDP growth, absolute poverty reduction, inflation and exchange rate stability, China has become one of the most successful developing countries in the world since

* Berlin School of Economics and Law. For helpful comments I thank two anonymous referees.

Correspondence Address:

Hansjörg Herr, Berlin School of Economics and Law, Badensche Str. 50 - 5I, I0825 Berlin, Germany, e-mail: hansherr@hwr-berlin.de.

Received Io January 2009, accepted 28 July 2009

(C) INTERVENTION 7 (I), 20IO, 7I-89 
the beginning of its reform process in 1978 . Nevertheless, there are also negative economic developments like the escalating inequality of income distribution as well as poor working conditions and ecological problems. In addition, since 2005 China has developed one of the most disturbing current account surpluses in the world - along with Japan and Germany. Irrespective of these problems it is a theoretically challenging question as to how China managed to trigger and sustain a long-lasting growth process which, in principle, could also have been combined with a more equal income distribution and a more careful handling of nature. China did not follow a big-bang strategy, which had been recommended by international institutions and followed by countries like the Soviet Union; nor did it follow the philosophy of neoclassical development models upheld by the Washington Consensus and the saving-gap model. Indeed, the Chinese miracle is difficult to imagine without a strong developmental state, and the non-acceptance of long-term deficits in the current account. But Chinese development is not unique in this regard. It is in keeping with the tradition of an Asian development model, as exemplified by Japan after World War II, and later by other Asian countries such as South-Korea, Singapore, and Malaysia. A key role in this model is played by the financial system (Stiglitz 1996, Stiglitz/Uy 1996). In this respect China is no exception.

The second section provides an overview of economic development in China. The third section deals with the Schumpeterian-Keynesian credit-investment-income-creation process. The financial system in China and its role for development is analysed in the fourth section, followed by concluding remarks in the fifth section.

\section{The Chinese economy}

\section{I Macroeconomic stability}

Between 1978 and 2008 annual real GDP in China (mainland, without Hong Kong) increased at a spectacular rate of nearly ten per cent on average, and GDP per capita grew by over eight per cent per annum (see Table I). Taking one US dollar a day as a measure, over the past decades China has been the country with the largest absolute reduction in poverty in the world, despite an alarming increase in income distribution inequality. An overall, gradual development strategy was chosen with far-reaching government interventions. For example, in the sequence of reforms, privatisation was put at the end of transition, while for decades property rights remained rather unclear. Prices were liberalised in several steps and quantity planning faded out slowly. China joined the World Trade Organisation in the year 200I. After 1978, international trade was largely regulated, however, regulations were reduced slowly. Even today it would be misleading to speak of a completely liberalised trade regime in China. 
Table I: Basic macroeconomic data for China $1978-2008$

\begin{tabular}{|c|c|c|c|c|c|c|c|c|}
\hline Year & $\begin{array}{c}\text { GDP } \\
\text { growth }^{*}\end{array}$ & $\begin{array}{l}\text { GDP per } \\
\text { capita } \\
\text { growth* }\end{array}$ & $\begin{array}{l}\text { Gross } \\
\text { capital } \\
\text { formation } \\
\text { as } \% \text { of } \\
\text { GDP }\end{array}$ & $\begin{array}{c}\text { Final } \\
\text { consumption } \\
\text { expenditure } \\
\text { as } \% \text { of GDP }\end{array}$ & $\begin{array}{l}\text { Exports } \\
\text { of goods } \\
\text { and } \\
\text { services } \\
\text { as } \% \text { of } \\
\text { GDP }\end{array}$ & $\begin{array}{l}\text { Inflation } \\
\text { rate } \\
(\mathrm{CPI}) * *\end{array}$ & $\begin{array}{c}\text { FDI net } \\
\text { inflows } \\
\text { as \% of } \\
\text { GDP }\end{array}$ & $\begin{array}{c}\text { Current } \\
\text { account } \\
\text { balance as } \\
\% \text { of GDP }\end{array}$ \\
\hline 1978 & 11.7 & 10.2 & 38.2 & 62.1 & 6.6 & 0.7 & 0.0 & $n / a$ \\
\hline 1979 & 7.6 & 6.1 & 36.1 & 64.4 & 8.6 & $n / a$ & 0.0 & $\mathrm{n} / \mathrm{a}$ \\
\hline 1980 & 7.8 & 6.5 & 34.8 & 65.5 & 10.7 & 7.5 & 0.0 & 0.1 \\
\hline 1981 & 5.2 & 3.9 & 32.5 & 67.1 & 12.7 & 2.4 & 0.1 & 0.8 \\
\hline 1982 & 9.1 & 7.5 & 31.9 & 66.5 & 12.3 & 1.9 & 0.2 & 2.0 \\
\hline 1983 & 10.9 & 9.3 & 32.8 & 66.4 & 10.9 & 1.5 & 0.3 & 1.4 \\
\hline 1984 & 15.2 & 13.7 & 34.2 & 65.8 & 11.3 & 2.8 & 0.5 & 0.6 \\
\hline 1985 & 13.5 & 11.9 & 38.1 & 66.0 & 10.0 & 9.3 & 0.5 & -3.8 \\
\hline 1986 & 8.8 & 7.2 & 37.5 & 64.9 & 11.8 & 6.5 & 0.6 & -2.4 \\
\hline 1987 & 11.6 & 9.8 & 36.3 & 63.6 & 16.4 & 7.3 & 0.9 & 0.1 \\
\hline 1988 & 11.3 & 9.5 & 37.0 & 63.9 & 17.1 & 18.8 & 1.0 & -0.9 \\
\hline 1989 & 4.1 & 2.5 & 36.6 & 64.5 & 16.7 & 18.0 & 1.0 & -1.0 \\
\hline 1990 & 3.8 & 2.3 & 34.9 & 62.5 & 19.2 & 3.1 & 1.0 & 3.1 \\
\hline 1991 & 9.2 & 7.7 & 34.8 & 62.4 & 21.0 & 3.4 & 1.2 & 3.3 \\
\hline 1992 & 14.2 & 12.8 & 36.6 & 62.4 & 22.5 & 6.4 & 2.7 & 1.3 \\
\hline 1993 & 14.0 & 12.7 & 42.6 & 59.3 & 23.3 & 14.7 & 6.2 & -1.9 \\
\hline 1994 & 13.1 & 11.8 & 40.5 & 58.2 & 24.6 & 24.1 & 6.0 & 1.4 \\
\hline 1995 & 10.9 & 9.7 & 40.3 & 58.1 & 23.1 & 17.1 & 4.9 & 0.2 \\
\hline 1996 & 10.0 & 8.9 & 38.8 & 59.2 & 20.1 & 8.3 & 4.7 & 0.8 \\
\hline 1997 & 9.3 & 8.2 & 36.7 & 59.0 & 21.8 & 2.8 & 4.6 & 3.9 \\
\hline 1998 & 7.8 & 6.8 & 36.2 & 59.6 & 20.3 & -0.8 & 4.3 & 3.1 \\
\hline 1999 & 7.6 & 6.7 & 36.2 & 61.1 & 20.4 & -1.4 & 3.6 & 1.4 \\
\hline 2000 & 8.4 & 7.6 & 35.3 & 62.3 & 23.3 & 0.4 & 3.2 & 1.7 \\
\hline 2001 & 8.3 & 7.5 & 36.5 & 61.4 & 22.6 & 0.7 & 3.3 & 1.3 \\
\hline 2002 & 9.1 & 8.4 & 37.9 & 59.6 & 25.1 & -0.8 & 3.4 & 2.4 \\
\hline 2003 & 10.0 & 9.3 & 41.0 & 56.8 & 29.6 & 1.2 & 2.9 & 2.8 \\
\hline 2004 & 10.1 & 9.4 & 43.2 & 54.3 & 34.0 & 3.9 & 2.8 & 3.6 \\
\hline 2005 & 10.4 & 9.8 & 43.7 & 51.8 & 37.3 & 1.8 & 3.5 & 7.2 \\
\hline 2006 & 11.6 & 10.5 & 45.5 & 48.0 & 40.1 & 1.5 & 3.0 & 9.4 \\
\hline 2007 & 13.0 & 12.5 & 42.6 & 47.1 & 42 & 4.7 & 4.3 & 11.1 \\
\hline 2008 & 9.9 & 8.5 & 40.8 & 48.2 & 27.3 & 5.8 & 4.1 & 9.9 \\
\hline
\end{tabular}

* In constant prices, change to previous year. ${ }^{* *} \mathrm{CPI}$ (Consumer Price Index), change to previous year. Source: China Statistical Yearbook (2009), World Bank (2009) 
Overall, China has managed to defend macroeconomic stability - measured in terms of inflation rate and GDP growth. Although inflation started to get out of control in the late I980 and especially in the early I990s - with an inflation rate of over 24 per cent in I994the country nevertheless managed to reduce the inflationary pressure without falling into recession. After the Asian crises, China suffered from a mild deflation for a few years, but this was also overcome and GDP growth was only slowed slightly in the process. After 2007 the inflation rate increased again as a result of higher food and energy prices, and a booming economy. Compared with other developing countries, the overall positive performance in terms of inflation rates and GDP growth led to a relatively high degree of confidence in the domestic currency and the domestic financial system. An erosion of the domestic monetary system never evolved.

\subsection{Capital controls}

Up to today, China has implemented a comprehensive system of capital controls, which has been relaxed somewhat only in the past few years. The logic of the capital control system is simple: all types of capital flows are controlled with the exception of foreign direct investment (FDI) inflows (Prasad/Wei 2005). This means that without permission Chinese banks, firms, households and public units are not allowed to take foreign credit or invest abroad. Compared with other developing countries - and measured as a percentage of GDP - China does not have a low level of international capital flows. However, capital inflows have been dominated by FDI and capital outflows by central bank interventions in the foreign exchange market. There have been illegal capital outflows - especially in the ro9os during and after the Asian crisis in 1997 - and illegal capital inflows. In particular, after 2002 China suffered from too high capital inflows: from high FDI inflows, financial inflows connected with FDI like credits between foreign parent companies and subsidiaries in China, and illegal capital inflows. All in all, however, capital controls have worked. To a large extent, China has been able to structure capital flows in its own interests, and in addition to follow a domestically oriented monetary policy with overall low real interest rates, a privilege not shared by many developing and even developed countries in the world (Herr 2008b).

Even compared with developed countries China has very low restrictions for FDI inflows. For example, the USA and Europe restrict FDI inflows to a much greater degree than China, arguing that technological and military secrets require protection. After 2005, China began to secure natural resources with FDI outflows (e.g. in Africa) or to obtain technology and export channels (e.g. in the United States or Europe). State funds from China and other developing countries that are used to buy banks and firms in Western countries are only partly welcomed.

Looking at FDI, successful Asian countries in the past - like Japan or South-Korea did not attract FDI in their development phases as they wanted to keep all keystone companies in national ownership. Obviously China was eager to catch up technologically very quickly, and/or was too backward - compared to Western countries - to imitate in the way Japan or other now relatively developed Asian countries did. 
In searching for the growth drivers in China it becomes clear that growth has been stimulated first and foremost by high investment. Growth rates in gross capital formation as well as the proportion of gross capital formation as a percentage of GDP (see Table I) have been extremely high. Over the whole transition period, the high investment dynamics was almost exclusively financed by domestic sources and in domestic currency. It would be misleading to consider FDI the main factor behind the high Chinese investment and economic development. FDI undoubtedly added to the dynamics of the Chinese economy, but the main effect of FDI has to be seen in the transfer of technology and management skills, and the opening of export channels. Firstly, while FDI inflows were almost non-existent in the 1980s, GDP growth was as high as in later decades when FDI inflows increased sharply. Secondly, from 1993 to 2008 FDI was on average about 7 per cent of gross capital formation in China (see Table I). This is relatively high, but FDI did not dominate investment. Thirdly, real FDI is probably much smaller because most FDI came from Hong Kong. To a certain extent this reflects that capital from the rest of China flows illegally to Hong Kong and comes back as FDI to exploit tax breaks and other privileges given to foreign investors. Fourthly, usually only a small part of FDI is part of gross capital formation, since the biggest parts usually reflect mergers $\&$ acquisitions and hence only changes in ownership. Finally, not all FDI has positive effects. For example some FDI, especially from Hong Kong and Taiwan, was low tech and therefore exploited only poor working conditions. After 2004 FDI inflows also added to the real estate bubble in coastal regions.

\subsection{The financial system and the pillars of the Chinese economy}

Quantity planning was gradually relaxed and faded out during the I980s. However, quantity planning was substituted by politically influenced quantitative credit expansion and credit allocation. Until the end of the I990s there was an official credit plan that fixed the credit volume and influenced credit allocation in the banking system. Even after the abolishment of the credit plan, credit rationing by the central bank and policy credits remained important. The Chinese economy is built on several important pillars.

a) As the first pillar, state-owned enterprises (SOEs) stimulated growth via high investment. China did also use SOEs for infant industry protection and to finance loss-making SOEs for social purposes. The SOE sector depended heavily on the official financial system. At the core of the official financial system are state-owned banks, especially the so-called "Big Four", which dominate the official banking sector. IBanks in the official financial system concentrated credit expansion on SOEs. However, over the years credits to other types of enterprises became more important. Naughton (2007: 478 ) reports that, although not included in official figures of the formal financial sys-

I The four banks are the Industrial and Commercial Bank of China, the Agricultural Bank of China, the Construction Bank and the Bank of China. 
tem, local government exercised control over substantial financial funds. At least indirectly, local authorities substantially influenced investment via control over local state-owned investment corporations and investment funds, which also provided finance for enterprises. In addition, firms directly issued debt-securities to private entities. In official statistics, "other « financial resources of investment of unclear origin make up about half of all formal bank lending. Part of this informal finance went to the SOEs, the rest to other sectors (see Figure I). Not much is known about the distribution of these funds and the informal credit markets. At the beginning of reform the SOE-sector dominated, with a share of over 80 per cent of industrial production in 1980 . Over the years this share declined considerably (National Bureau of Statistics 2009, China Statistical Yearbook 1996). In 2007 state-owned and state-holding industrial enterprises comprised six per cent of all industrial enterprises, employed over 20 per cent of the industrial workforce, and produced 29.5 per cent of industrial output (Gabriele 2009: 9). The SOE sector developed in different phases. In the r980s SOEs were profitable on the whole due to their monopolistic position. This changed in the I990s when the booming private sector and foreign companies intensified competition in the goods market. In particular, small SOEs with backward technology accumulated losses, and were financed by state banks for social reasons. In the late r99os the Chinese government started the policy »keep the big, dump the small«. Many lossmaking small SOEs were shut down, and the bigger SOEs were successfully restructured. After ten years of restructuring the SOE sector became profitable and in many respects more dynamic than the private Chinese-owned enterprises sector. For example, most domestic research is located in SOEs (Woetzel 2008, Gabriele 2009, Lo 1999). ${ }^{2}$ It looks as if the SOE sector will remain the backbone of domestically-based Chinese industrial development for some time.

Figure I: Financial system and investment sectors in China

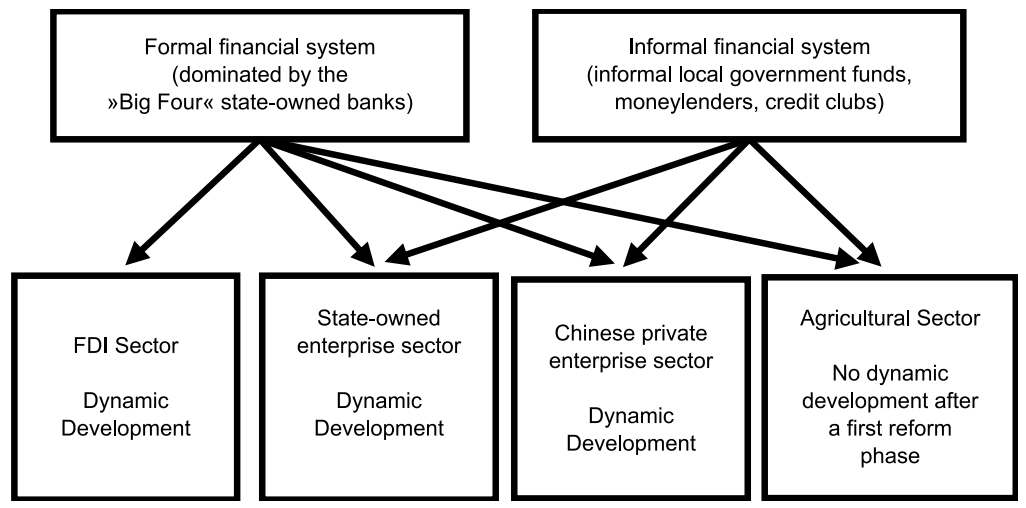

2 Sachs/Woo (1994) also support the argument that Chinese SOEs increased efficiency in the I980s. However, they argue that during that period private companies performed better. 
b) In the early 1990s China started to open up for FDI, with foreign ownership in the enterprise sector starting to expand quickly. First only joint ventures were allowed. Since the end of the I990s the number of wholly-owned foreign enterprises increased quickly. In 2007, so-called Foreign Funded Enterprises produced 2I per cent, and Enterprises with Funding from Hong Kong I0.5 per cent of industrial output (China Statistical Yearbook 2008). These enterprises have had access to both foreign funds and the formal financial system in China.

c) A third pillar consists of private market-based enterprises owned by Chinese. These enterprises have usually been small or medium-sized. After 1978 a Manchester type of capitalism - with waves of new enterprise foundations and bankruptcies - developed in this sector. This is generally the sector with very poor working conditions, no safety net, and a low level of legal enforcement. This is also the sector with virtuous and vibrant private entrepreneurialism which boosted GDP growth (Huang 2009). However, it would be wrong to consider this sector as the main engine of development. It was the interaction between the state-controlled sector and the private, purely market-based sector which is behind the dynamic Chinese development. Development in the purely market based sector was not only positive. Productivity in this sector is in most cases very low. It also led to a largely deregulated labour market, and is one of the reasons for the high level of unequal income distribution in China at present. ${ }^{3}$ For a long time the Chinese private enterprise sector had very limited access to the official financial system, which served SOEs first. These enterprises financed their investment mainly out of profits, or by means of credit from the informal financial system.

d) The last sector is the agricultural sector. In the late 1970s China switched from collectively organised agricultural production to a family-based leasing system, creating a system of very small farms. In the first five years after the reform agricultural production increased substantially, but after this period this sector lost its momentum, and hasn't yet recovered. Farmers have access to the formal financial system. However, moneylenders and unregistered banks play a significant role, especially in the agricultural sector credit clubs. In 1986, for example, household surveys revealed that informal credits in this sector surpassed formal lending (Naughton 2007: 478).

\subsection{The exchange rate regime and the current account}

In the I980s China experimented with several exchange rate regimes. In 1981 a dual exchange rate regime was established which fixed different exchange rates for different types of transactions. In 1985 the primary exchange rate for international trade was allowed to float. Beginning at the end of the 1980s, this exchange rate started to depreciate sharply and lost

3 The traditional development model in East Asia went hand in hand with a much more equal income distribution. In China this has not been the case. The Chinese government became worried about the development in the labour market and assigned the state-controlled unions to control legal enforcement and improve working conditions (Zenglein 2008). 
nearly 50 per cent of its value - vis-à-vis the US dollar - by the end of I993. In 1994 the two exchange rates were unified, and pegged unofficially to the US dollar, with the value of the floating exchange rate chosen for the peg. Thus China pegged its exchange rate at a level which made Chinese products internationally competitive. This peg was successfully defended until 2005, when China started to peg the renminbi (RMB) to a currency basket and a crawling peg regime with moderate periods of appreciation vis-à-vis the US dollar.

After 1978 China began following a policy of avoiding long-term deficits in the current account. Indeed, since the second half of the I990s high growth rates of exports and permanent current account surpluses have characterised Chinese development. The moderate surpluses started to explode in 2003, and let China join Japan and Germany as the countries with high exports and current account surpluses. ${ }^{4}$ Next to high investment, exports became the second most important engine for demand and growth in China after the mid I99os.

It is frequently argued that cheap Chinese wages are responsible for high Chinese export surpluses. But what remains vague in this argument is how wages are measured. If real wages are meant, the question is why countries like Uganda - with similarly low wages have huge current account deficits. If nominal wages are taken, it is the exchange rate which makes the wages of a country low in comparison to other countries. In China, the People's Bank of China (PBoC) - the Chinese central bank - has been steadily intervening in the foreign exchange market to prevent or slow down an appreciation of the Chinese RMB. To date, China has accumulated the highest foreign exchange reserves in the world, amounting to around 2 trillion US dollars in 2009 (SAFE 2009). Thus, the PBoC is the cause of the high Chinese current account surpluses. Since the end of the I990s China has amassed a huge double surplus, a surplus in the current account and a surplus in the capital account, stemming from FDI and speculative capital inflows. ${ }^{5}$ Without the PBoC's interventions in the foreign exchange market, and without changes in capital flows, China would be pushed into a constellation with a current account deficit.

There is no doubt that China's current account surpluses are harmful for economic growth in other countries - as are the high surpluses of Germany and Japan. Germany realises most of its surpluses in Europe which is becoming a major problem for the European Monetary Union (Herr/Kazandziska 2007), while Japanese surpluses are as problematic for the world economy as the Chinese. It would seem highly desirable for the world economy to find an effective mechanism to halt destabilising current account imbalances. China is merely one part of a larger problem that needs to be solved. As a result of capital controls, and a policy to avoid current account deficits, China has never suffered from a currency crisis after the start of the reform period in 1978. In early 2009 Chinese foreign debt of around 300 billion US dollars was only about Is per cent of official foreign reserves (SAFE 2009). Even the Asian crisis in 1997 only reduced the Chinese growth rate indirectly, while as a re-

4 Resource-rich countries like Russia and the Arabic countries also realised very high current account surpluses after 2003 .

$5 \quad$ The explosion of the Chinese current account surplus in recent years may reflect some illegal capital inflows as exporters artificially increase export prices to transfer funds to China. 
sult of deregulated financial markets, neighbouring countries suffered from severe currency crises, recessions, and depreciated sharply vis-à-vis the RMB which kept its dollar peg. In contrast to many other developing countries, it has been the absence of currency crises that has allowed China to develop without interruption, and there has never been the danger of a currency crisis pushing China away from its very dynamic growth path.

In China the saving rate is high. The household saving rate increased from a level of 5 per cent in 1978 to around 25 per cent in the 2000 (China Statistical Yearbook 2009). This high rate of saving reflects - at least in part - the unequal income distribution, and the underdeveloped and deficient social safety-net in China (Naughton 2007: $428 \mathrm{ff}$.). Throughout the 200os, private consumption as a percentage of GDP has dropped to around 50 per cent - a very low level by international standards (Table I). High saving rates usually lead to a lack of demand and reduce GDP growth. In the Chinese constellation of high investment demand and high export surpluses, the high saving rate reduced the danger of economic overheating and thus can be considered positive. ${ }^{6}$

The high proportion of exports as a percentage of GDP makes Chinese growth very dependent on world market development, especially on development in the USA as the main market for Chinese exports. To come to a more balanced demand structure, the share of consumption on GDP has to be increased and exports surpluses reduced.

\section{Credit and growth - The theoretical debate}

It was Schumpeter (1934) who argued that development is only possible if innovative entrepreneurs receive credit to invest that is created ad hoc - or "out of nothing", as in the German original. Keynes (1937a, I937b) also argued along these lines when he emphasised that the investor needs cash to carry out investment. What is necessary for economic development is new credit created first and foremost by the banking system (Herr 2008a). ${ }^{7}$

In Figure 2 (on p.80), such a process is shown in a stylised way. It starts when the banking system gives new credit to firms for investment. With the help of the central bank, commercial banks can create additional credit »out of nothing «. The act of credit creation leads automatically to the creation of additional monetary wealth, since a banking system simply gives credit by increasing its deposits or lengthening its balance sheet. The most important point here is that additional credit leads to additional investment. Then investment creates demand in the goods market, additional capacity, production and employment, additional

7 Keynes (1937c) argued that, corresponding with their expectations, wealth owners would switch between hoarding (keeping liquidity) and giving funds to firms (keeping bonds and long-term shares). For him this was the most important source of finance. In his approach the private wealth owner (wrongly) becomes of paramount importance. In Schumpeter's thinking banks are much more important and are the key to the creation of the funds firms need to expand. Both approaches supplement each other. 
income in the form of wages and profits, and finally also savings. What we can see here is a credit-investment-income-saving mechanism including the well-known goods market multiplier process. Savings are kept by the public as cash, as long-term funds given to firms or banks, or as liquidity in the form of short-term bank deposits. Banks are needed as "circuit starters « for investment and production (Bossone/Sarr 2002). However, the central bank has to accommodate an expansion process by refinancing commercial banks, because part of central bank money will trickle away in additional cash holdings of the public and additional reserve holdings of banks.

Figure 2: The credit-investment-income process

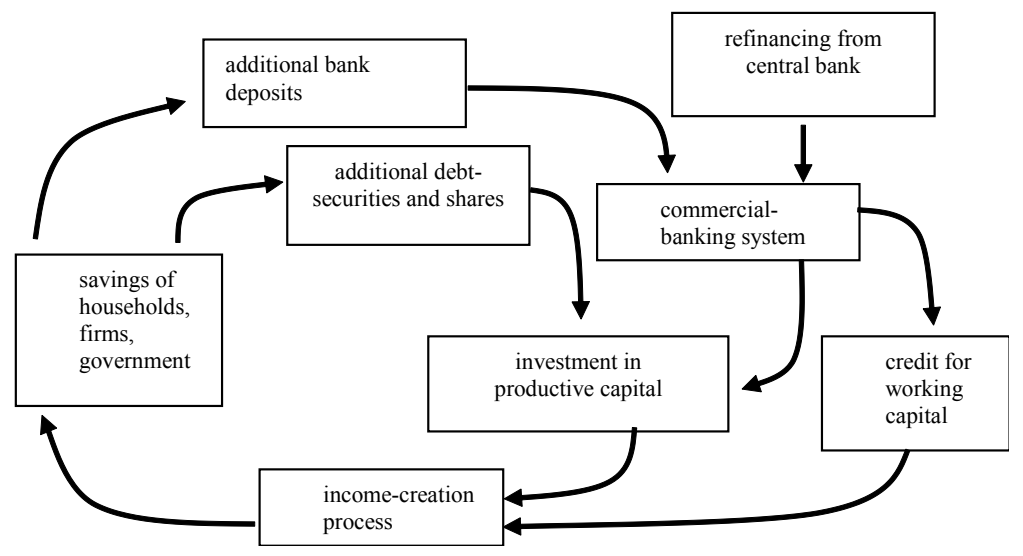

Source: Priewe/Herr (2005: 152)

Of course, finance is not the only factor needed to create development. For example, there must be entrepreneurs to invest in productive activities. Economic expansion can also be inflationary: if demand becomes too high, and a demand-driven inflation triggers a wageprice spiral. Sooner or later central banks have to fight inflation. In such a situation the central bank becomes a circuit stopper, as restrictive monetary policy will lead to a slowdown of demand, to lower credit expansion, and to a reduction in GDP growth and employment.

Credit expansion can only lead to development when credits are used for investment in the real economy. If credit is expansion is used to finance asset price bubbles in the stock market or the real estate sector sustainable development is not possible. Many developing countries had bank based financial systems and could prevent credits going to asset markets (for Asia cp. Stiglitz/Uy I996). If this is not guaranteed the link between credit expansion and development breaks down.

Taking the relation between domestic bank credit (in domestic and foreign currency) to GDP, or domestic credit to the private sector (in domestic and foreign currency) to GDP as an indicator, a close link between the development of the financial system and the level of per capita income is revealed (see Table 2). In some low-income or even middle-income countries domestic bank credit to GDP, and domestic credit to the private sector is 
extremely low. In these countries a domestically based credit-investment-income mechanism is obviously not working. Indeed, in many of these countries the domestic financial systems are fundamentally distorted and unable to deliver sufficient credit. It is noteworthy that China, a low-income country, has credit ratios that are well above the level of a low-income country, and come close to reaching the levels of developed countries. One of the secrets of the Chinese development can be found in this extraordinary development of domestic credit (see Table 2).

Table 2: Domestic credit in per cent of GDP in 2007 in selected countries*

\begin{tabular}{l|cc}
\hline & $\begin{array}{c}\text { Domestic bank credit to the } \\
\text { private sector as a percentage } \\
\text { of GDP }\end{array}$ & $\begin{array}{c}\text { Domestic credit to the private } \\
\text { sector as a percentage of GDP }\end{array}$ \\
\hline Low-income countries & 37 & 31 \\
\hline Middle-income countries & 75 & 60 \\
\hline High-income countries & 195 & 163 \\
\hline China & & 111 \\
\hline Armenia & 132 & 14 \\
\hline Bangladesh & 12 & 37 \\
\hline Brazil & 58 & 50 \\
\hline Cambodia & 96 & 18 \\
\hline India & 13 & 47 \\
\hline Korea, Rep. & 64 & 108 \\
\hline Malaysia & 110 & 105 \\
\hline Mexico & 113 & 22 \\
\hline Mongolia & 38 & 46 \\
\hline Peru & 30 & 21 \\
\hline Russian Federation & 16 & 39 \\
\hline
\end{tabular}

* Credit in domestic and foreign currency.

Source: World Bank (2009)

There are several explanations for the low ratio of credit to GDP in developing countries. Firstly, developing countries usually suffer from low trust in their domestic currencies. In the hierarchy of currencies they find their currencies at the bottom. In many cases wealth owners in these countries prefer to keep large parts of their monetary wealth in US dollars, euros or in other currencies at the top of the currency hierarchy. Capital flight and dollari- 
sation ${ }^{8}$ are indicators of this fact. Central banks, as mentioned above, will accommodate a circuit of domestic credit expansion, investment and growth as long as there is no inflationary danger. The key point is that developing countries are confronted with a systematically tighter restriction in credit expansion than developed countries, and they have a harder macroeconomic monetary budget constraint. ${ }^{9}$ One example helps to illustrate this. Let us assume that Ioo units of credit and monetary wealth in domestic currency are created in a typical developing country with a low reputation currency. According to the preference of wealth owners, a certain percentage of the newly created wealth will be exchanged in hard currencies. If wealth holders want to keep 50 per cent of their monetary wealth in hard currency inside and/or outside of the country - a very conservative assumption for most developing countries - 50 units of domestic wealth in domestic currency will be exchanged into hard currency. This leads to a depreciation of the domestic currency, which can only be absorbed to a limited extent by a developing country. Firstly, depreciation may trigger inflationary processes, especially because in developing countries prices and wages are sometimes explicitly or implicitly pegged to the exchange rate. Secondly, in developing countries foreign debt is almost exclusively denominated in foreign currency - another consequence of the poor quality of their currencies - with the consequence that any real depreciation leads to an increase in the real debt burden of debtors in foreign currency. Thirdly, the export and import elasticity is very low, in which case very large real exchange rate movements are needed to improve the trade balance. Depreciations can even worsen the trade balance. And finally, a real depreciation may lead to such a reduction in real income that part of the population falls into absolute poverty. It follows that countries with low-quality currencies have to rapidly stop domestic credit expansion in domestic currency, as they cannot accept large and permanent depreciations of their currencies. They are not able to initiate a strong and sustainable domestically-based Keynesian-Schumpeterian credit-investment-incomecreating process which is the backbone of economic development.

Countries with a lack of domestic credit can tap foreign financial markets. However, tapping foreign financial markets involves high risks of failure. Firstly, foreign credit in developing countries is nearly always denominated in foreign currency. Under this condition any sharp depreciation increases the real debt burden of domestic debtors and leads to simultaneous currency and banking crises. As international capital flows are unstable, developing countries relying on foreign credit are likely to suffer from boom-bust cycles and pe-

8 Dollarisation includes euroisation, other currencies only play a marginal role in this field. Dollarisation means that monetary wealth is kept inside the country in foreign currency. It can be understood as capital flight inside the country by small wealth owners who do not have the opportunity to keep wealth abroad. Deposit dollarisation in many developing countries exceeds 50 per cent (De Nicoló et al. 2003). In addition, especially in countries with unstable banking systems and where the danger of confiscation of monetary wealth exists, foreign bank notes are hoarded. Adding capital exports or capital flight in most developing countries domestic wealth holders keep most of their monetary wealth in foreign currency.

9 Kornai (1980) spoke about monetary budget constraints to distinguish between market economies (hard budget constraints) and planned economies (soft budget constraints). 
riodic currency crises. Secondly, even without the danger of currency crises, capital inflows may erode the competitiveness of developing countries and lead to long-term negative effects similar to the widely discussed Dutch disease effects. ${ }^{10}$

Typically, financial systems in developing countries do not offer sufficient long-term credit, or credit for all sectors in the economy. Private banks usually do not grant long term loans in developing countries, as debtors lack collateral and banks judge the general situation in the country as uncertain and too risky. It is common in developing countries that share markets and markets for enterprise bonds - which could provide long-term funds are underdeveloped or do not work properly (Stiglitz/Uy 1996). These problems aggravate the predicament evolving from capital flight and dollarisation even further.

\section{Credit and growth - The Chinese case}

Development in China would not have been possible without the financial system supporting and pushing investment. It is important to recognise here that capital export controls and relatively low dollarisation prevented the early curtailing of domestic credit expansion, which is the explanation of the low ratio of domestic bank credit to GDP in so many developing countries. Overall, capital export controls in China have worked well, and compared to other developing countries dollarisation in China is relatively low. Domestic foreign currency deposits and domestic foreign currency credits as a percentage of total domestic aggregates were about five per cent in 2009 (PBoC 2009). Last but not least, and as mentioned above, the relatively low level of foreign debt in China, combined with the policy of striving for current account surpluses prevented currency crises and interruptions to the growth process by external factors.

Let us analyse the formal financial system in China in more detail. China has a bankbased financial system. Corporate bonds and stocks do not substantially add to the financial funds available for firms. For example, between 2000 and 2005 over 70 per cent of all funds in the domestic financial system were bank lending." system is the group of four big state-owned commercial banks. These were created in the I980s when the mono-bank of the planning system was divided into a two-tier banking system with the $\mathrm{PBoC}$ as the central bank, and the "Big Four « as state-owned commercial banks. Only recently was part of the equity of the »Big Four « sold to foreign investors, albeit without giving up government control. In the 1980 os the »Big Four « completely dominated the financial system. In 2005 they still held 52.5 per cent of the assets of all banking institutions. The second biggest single group of banks - with 15.5 per cent of all bank assets in 2005 - are the joint-stock commercial banks, which are mainly owned by state-owned enterprises

Io Countries which are rich in natural resources may suffer from appreciation and a crowding-out of the manufacturing and export sectors. The same effect appears as a result of high development aid. High private capital inflows can also lead to appreciation and Dutch disease effects.

II See for this and the following figures Naughton (2007: 45Iff.) 
and government agencies, and generally controlled by local governments. About $100 \mathrm{com}-$ mercial city banks exist, which are controlled by local governments and keep around 5.4 per cent of bank assets. Since the r 950 os rural credit cooperatives have taken over the function of financing farmers. In 2005 rural credit cooperatives held 9.9 per cent of banking institutions' assets. Finally, in 1994, three so-called state-owned policy banks were founded to finance special government objectives in the field of infrastructure projects, export promotion and agricultural development. ${ }^{12}$ Together, these banks are slightly smaller than the credit cooperatives. Other banking institutions have remained unimportant until today; foreign banks were negligible in 2005. Since 2006, according to WTO regulations, foreign banks have been allowed to conduct business in RMB. In the future, the share of foreign banks may increase slowly.

Monetary policy in China reflects the East Asian tradition. Lending and deposit rates for all banks have been set by the PBoC. Real interest rates were set at low levels for deposits and lending; negative real interest rates were avoided in principle. At least until the late I990s, as long as the credit plan was officially in place, the PBoC fixed official credit ceilings for the banking system. Competition between banks was limited as the interest rate was set administratively. China does not suffer from a lack of credit demand. Many of the state-owned firms continued to function in part like firms under quantity planning and had a high investment hunger`. However, high credit demand must also be interpreted as a reflection of high ranimal spirits or entrepreneurship on the basis of a stable expansion path. As not all credit demand could be fulfilled, the financial system in China was characterised by strict credit rationing. ${ }^{13}$ Today -2009 - the PBoC continues to set bank deposits and lending rates, and uses legal reserve requirements and moral persuasion to control credit volumes.

Overall, China managed to control aggregate credit volumes and was able to keep inflation at low levels most of the time, while reducing inflation rates when they became too high. Defending macroeconomic stability was not always easy for the PBoC. For example, in the early I99os inflation became a problem as commercial banks found ways to circumvent credit ceilings by creating and financing non-bank financial institutions, which mushroomed during those years. The 1994 banking reform in China re-established macroeconomic

I2 The three banks are the China Development Bank, the Export-Import Bank and the Agricultural Development Bank.

I3 For economists, thinking in traditional credit market models with smooth demand and supply functions of credit and an equilibrium which allows all credit demanders to get a loan if they pay the equilibrium interest rate credit rationing is something negative. But even completely liberalised credit markets do not function according to the traditional model. Banks in liberalised credit markets will only grant a loan if the potential debtor can offer good collateral or convincing projects. Stiglitz/Weiss (I983) correctly pointed out that under the assumption of asymmetric information banks will not demand the highest interest rate possible which will equalise credit demand and credit supply. Banks will prefer to keep interest rates low and ration credit, so as not to drive away good debtors like serious entrepreneurs who do not invest if interest rates are too high. 
control. Many of the non-bank financial institutions were closed, and China implemented a partially segmented financial system and commercial bank share-holding was limited.

For a full two decades after the start of reform in 1978 formal credit allocation was to a large extent policy-driven. The credit plan fixed the overall credit volume of the "Big Four«, including the regional allocation of the credit volume. There was a form of negotiation between the provinces and the central government in Beijing as to how much of the national credit cake should go to the various provinces and how much would be retained in Beijing. On a provincial level, credit allocation was negotiated between the local government, the local branches of the commercial banks, the local branch of the PBoC, and firms. The local government was by far the most powerful player in this credit allocation mechanism. In addition, politics strongly influenced the credits given by joint-stock commercial banks, city banks, credit cooperatives, and of course the policy banks. The bulk of the formal credits went to SOEs, but private enterprises - especially those with good relations to cadres had access to the formal credit system. ${ }^{\text {I4 }}$

Credits were allocated according to different priorities and motivations: Firstly, they were used to finance investment in selected industries, firms and regions. There was definitely not a coherent national development plan for industrial policy, but there was the general attitude on all levels to support development and efficiency. This credit expansion in the formal financial system became the backbone of the dynamic quantitative and qualitative investment development in China. It has stimulated high investment with all of its multiplier effects for the other sectors of the economy (Herr/Priewe 1999).

Secondly, loss-making firms were financed to prevent their bankruptcy, which would have led to a rapid increase in unemployment and poverty. As in all planned economies, China's social safety-net was built around the firms. A big-bang strategy to close all lossmaking SOEs would have led to substantial social and political distortions. Financing lossmakers can be interpreted as the unavoidable costs of maintaining social coherence. Banks took over fiscal functions.

The non-performing loan problem escalated in the second half of the I990s. SOEs came under increasing pressure from the growing Chinese private sector - which did not have to pay for a welfare state system - and from a growing foreign investment sector that usually used superior imported technology. These developments led to the accumulation of non-performing SOE loans. The resulting financial pressure triggered the privatisation of the least productive small and medium-sized SOEs (Lau 1999). The restructuring of the SOE sector in the 2000 s was successful. Together with repeated policies to transfer bad credits to special government controlled institutions, and re-capitalisations of the banks, it was possible to reduce the problem substantially. Official Chinese data reveal that for 1995 the non-performing loans of the »Big Four« amounted to 2I.4 per cent. After that it increased gradually until 2000 to 29.2 per cent. In 200 , it was reduced to 25.4 per cent and by the end 
of 2007 it was only 6.I7 per cent (China Banking Regulation Commission 2008). ${ }^{\text {is }}$ These figures may not divulge the full extent of the problem, but they show that the problem is under control. And we should not forget that - to a large extent - non-performing loans present quasi fiscal deficits, as banks took over government functions to finance the social safety-net in SOEs, especially in the I990s. Lastly, non-performing loans are denominated in domestic currency. This stands in sharp contrast to many over-indebted developing countries, where debts are held in foreign currency.

In I998, the credit plan was officially abandoned, with the aim of a more market-based credit allocation. Banks were forced to act more like normal banks in market economies, and the private sector became a more important customer for the banks. In addition, the capacity of local governments to influence credit allocation was reduced. The PBoC, for example, abolished 3I provincial branches and established nine regional branches with a higher degree of independence from local governments (Cao 200I). However, the transition process in China is gradual, and the process varies in different provinces and counties. Local governments still maintain substantial control over credit allocation. Also, for good reasons the $\mathrm{PBoC}$ is still not using the interest rate as the main tool to carry out monetary policy. Credit volumes of the »Big Four" are controlled indirectly and where needed, directly. However, compared with the decades before, the power to prevent credit expansion going to asset markets like the real estate market has been eroding. This means that the danger of asset price bubbles in China increased.

The quantitative dimension of the informal credit market in China is not completely clear. However, it seems evident that the informal credit market supported Chinese dynamics as it delivered finance to firms which were excluded from the formal credit market.

\section{Conclusion}

The secret of Chinese success seems to rest on a productive combination of government interaction and market forces. China has managed to create a sustainable SchumpeterianKeynesian credit-investment-income-creation process which has led to economic prosperity. This process was domestically driven by political credit expansion and allocation, and by a dynamic private sector including foreign enterprises. The expansion process has been externally protected by strict capital controls, and a policy of avoiding current account deficits, high foreign debt and high dollarisation. The typically distortion of domestic financial systems within developing countries - with chronic capital flight and dollarisation, in addition to a chronic lack of long-term and cheap financial funds for almost all enterprises - cannot be found in China.

I5 In 2004 the relation of domestic credit to GDP in China was I66.9 per cent. The drastic reduction of the ratio to I2O per cent in 2005 reflects that balance sheets were cleared of non-performing loans (World Bank 2006 and 2007). 
The Chinese development model was very much shaped by the transition process from a planned economy to a market economy, and the gradual process which characterised the transition. In the meantime, the transition is over and China has become a capitalist country. However, its capitalist model is a specific one, and a version of the Asian type of capitalism which was so successful in Japan and many other countries after World War II. It is important to stress this point to avoid interpreting the dynamic of the Chinese economy as being due to the transition, which will be over as soon as the transition is over. It is not clear how China will develop in future. At least up until the subprime crisis - which hit the world after 2007 - it looked as if the Chinese elite had the intention of establishing a US-type of liberal market capitalism in the long run. This may have changed after the subprime crisis, and China is probably now searching for ways to further develop its own unique variety of capitalism. China could then become an important player in the search for new successful development models, together with other developing or emerging markets like India or Brazil.

Other developing countries can learn from China. Of course, certain Chinese institutions of credit allocation might be difficult to copy - or may not be desirable. Also, some dimensions of Chinese development - the unequal income distribution, the ecological problems or the extreme current account surpluses after 2003 - are negative and unnecessary. Development in China would have been possible without such negative development. And it is imperative for every country to look for their own solutions, as one approach never fits all. However, China is an excellent example of the success of a domestically based financial system protected from the world market, serving the enterprise sector and supporting high economic growth. At the same time China did not follow a strategy to isolate itself from the world market. Certain types of capital flows, especially FDI, were allowed and even stimulated. China quickly has become an important player in the international division of labour. Export promotion and competition in international markets has been the main strategy in this area, and not import substitution which in many cases protect the weak and do not support strong enterprises. China also teaches us that a policy which does not focus on a static concept of optimal allocation - in the tradition of neoclassical thinking - can be extremely successful.

Chinese policies to stimulate growth may not look acceptable through a neoclassical lens, but they have been successful in financing and supporting animal spirits and entrepreneurship in the private and public enterprise sectors. A Martian looking down on earth would be very surprised by world famous institutions like the International Monetary Fund and the World Bank, employing as they do so many experts who have not recommended the Chinese development model (Rodrik 2005). In the tradition of the so-called Washington Consensus these institutions recommended deregulation, liberalisation, quick privatisation, and a slim government - usually without success; just as the subprime financial crisis development in China is an intellectual challenge for mainstream economic thinking. Therefore, this is an opportune time to reassess economic thinking in general, and development in particular. 


\section{References}

Bossone, B., Sarr, A. (2002): A new financial system for poverty reduction and growth, IMF Working Paper No. 02/178, Washington D.C.

Cao, T.G. (200I): The People's Bank of China and its monetary policy, Business Institute at the FHW Berlin, Working Paper No. I4, URL: http://www.fhw-berlin.de/fileadmin/ downloads_internet/Forschung/Veroeffentlichungen/Working_paper/working_paper_ I4.pdf.

China Banking Regulation Commission (2008), Beijing.

China Statistical Yearbook (different years), Beijing.

De Nicoló, G., Honohan, P., Ize, A. (2003): Dollarization of the banking system: Good or bad?, IMF Working Paper No. 03/146, Washington D.C.

Gabriele, A. (2009): The role of the state in China's industrial development: A reassessment, MPRA Paper No. I455I, URL: http://mpra.ub.uni-muenchen.de/I455I/I/MPRA_ paper_I455I.pdf.

Herr, H. (2008a): Financial systems in developing countries and economic development, in: Hein, E., Niechoj, T., Spahn, P., Truger, A. (eds.), Finance-led Capitalism? Macroeconomic Effects of Changes in the Financial Sector, Marburg: Metropolis.

Herr, H. (2008b): Capital controls and economic development in China, in: Arestis, P., De Paule, L.F. (eds.), Financial Liberalisation and Economic Performance in Emerging Markets, Cheltenham: Edward Elgar, I42-I72.

Herr, H., Kazandziska, M. (2007): Wages and regional coherence in the European Monetary Union, in: Hein, E., Priewe, J., Truger, A. (eds.), European Integration in Crisis, Marburg: Metropolis.

Herr, H., Priewe, J. (1999): High growth in China - Transition without a transition crisis?, in: Intereconomics, 34, 303-316.

Huang, Y. (2009): Private ownership: The real source of China's miracle, in: McKinsey Quarterly, 23.9.2009, URL: https://www.mckinseyquarterly.com/home.aspx.

Keynes, J.M. (1937a): The rex-anter theory of interest, in: The Economic Journal, 47, 663 - 669.

Keynes, J.M. (1937b): Alternative theories of the rate of interest, in: The Economic Journal, $47,24 \mathrm{I}-256$.

Keynes, J.M. (1937c): The General Theory of Employment, in: The Quarterly Journal of Economics, 5I, 209-223.

Kornai, J. (1980): The Economics of Shortage, North-Holland: Amsterdam.

Lau, R.W.K. (1999): The I5th Congress of the Chinese Communist Party: Milestone in China's privatization, in: Capital and Class, 68, 51 - 87.

Lo, D. (1999): Reappraising the performance of China's state-owned industrial enterprises. I980 - 1996, in: Cambridge Journal of Economics, 23, 693-718.

National Bureau of Statistics (2009), Beijing.

Naughton, B. (2007): The Chinese Economy. Transition and Growth, Cambridge, MA: MIT Press. 
Nitsch, M., Diebel, F. (2008): Guanxi Economics: Confucius meets Lenin, Keynes, and Schumpeter in contemporary China, in: Intervention. European Journal of Economics and Economic Policies, 5, 77 - IO4.

People's Bank of China [PBoC] (2009): URL: http://www.pbc.gov.cn.

Prasad, E., Wei S.J. (2005): The Chinese Approach to Capital Inflows, IMF Research Department, Washington, D.C.

Priewe, J., Herr, H. (2005): The Macroeconomics of Development and Poverty Reduction, BadenBaden.

Rodrik, D. (2005): Growth strategies, in: Aghion, P., Durlauf, S. (eds.), Handbook of Economic Growth, Vol. I, Elsevier: North-Holland, 967-Ior4.

Sachs, J., Woo, W.T. (1994): Understanding the reform experiences of China, Eastern Europe and Russia, in: Lee, C., Reisen, H. (eds.), From Reform to Growth: China and Other Countries in Transition, Paris: OECD, 2I-64.

State Administration of Foreign Exchange [SAFE] (2009): Annual Report 2009, Beijing.

Schumpeter, J. (1934): The Theory of Economic Development (first German edition I9II), Cambridge, MA: Harvard University Press.

Stiglitz, J.E. (1996): Some lessons from the East Asian miracle, in: World Bank Observer, II, I5I - I77.

Stiglitz, J.E., Uy, M. (1996): Financial markets, public policy, and the East Asian miracle, in: The World Bank Observer, II, $249-276$.

Stiglitz, J.E., Weiss A. (1983): Incentive effects of termination: Applications to the credit and labour market, in: American Economic Review, 73, 912 - 927.

Woetzel, J.A. (2008): Reassessing China's state-owned enterprises, in: McKinsey Quarterly, 8.7.2008, URL: https://www.mckinseyquarterly.com/home.aspx 3.

World Bank (different years): Development Indicators, Washington D.C.

Zenglein, M. (2008): Marketization of the Chinese labor market and the role of unions, Global Labour University Working Papers No. 2, URL: http://www.global-labouruniversity.org/I64.html. 
